\title{
26S Protease Regulatory Subunit 7
}

National Cancer Institute

\section{Source}

National Cancer Institute. 265 Protease Regulatory Subunit 7. NCI Thesaurus. Code C106091.

$26 \mathrm{~S}$ protease regulatory subunit 7 ( $433 \mathrm{aa}, \sim 49 \mathrm{kDa}$ ) is encoded by the human PSMC2 gene. This protein is involved in both the regulation of proteasome-mediated degradation of ubiquitinated proteins and ATP hydrolysis. 